\title{
Assessment of Spatial Variability of Soil Nutrient Status in Rice Ecosystem Using Nutrient Index in Anaimalai Block, Coimbatore
}

\author{
K. Theresa*, R. Shanmugasundaram and J.S. Kennedy
}

Department of Soil Science and Agricultural Chemistry, Department of Agricultural Entomology, Tamil Nadu Agricultural University, Coimbatore, India

*Corresponding author

\section{A B S T R A C T}

\section{Keywords}

Rice, Nutrient index, Macro and micro nutrients, Anaimalai block

Article Info

Accepted:

17 July 2019

Available Online:

10 August 2019
Geo referenced soil survey was undertaken in rice growing areas of Anaimalai Block, Coimbatore district of Tamil Nadu. The main aim of this study was to carry out the evaluation of soil fertility and fertilization practices being followed by the rice growing farmers of the selected villages in Anaimalai block. Soil samples were collected from 18 villages with an auger from a depth of $0-15 \mathrm{~cm}$ and analyzed for $\mathrm{pH}$, electrical conductivity, organic carbon, available macro and micro nutrients using standard analytical methods. These data were used to spot the range of critical soil available nutrient and the relationships among the soil fertility parameters. Based on the results obtained, soil reaction was neutral to alkaline in nature. Electrical conductivity was found to be in safer limit $\left(<1 \mathrm{dS} \mathrm{m}^{-1}\right)$ and almost 70 per cent of the villages fall under the medium category of soil organic carbon content. Results indicated that 70 percent of the samples are low to medium in available nitrogen; for Olsen $\mathrm{P}$, it was 55 percent in medium status, 25 percent of the samples was under the highest $\mathrm{P}$ category $\left(16-22 \mathrm{~kg} \mathrm{ha}^{-1}\right)$; and about 80 per cent of the samples were medium in $\mathrm{NH}_{4} \mathrm{OAc}-\mathrm{K}$. Except $\mathrm{Cu}$, other micronutrients were deficient. From the nutrient index, $\mathrm{Cu}$ was above sufficiency range, $\mathrm{P}$ and $\mathrm{Fe}$ were found to be adequate and the other elements were deficit in soil.

\section{Introduction}

In the back drop of food crisis gripped India during 1960's the concept of green revolution was commenced to meet human need of fast growing population. Agriculture production was attentively considered as a main target to satisfy food constraints among the raising population. Traditional farming methods gave way to farming with high yield seeds, fertilizers and pesticides. Subsequently India has achieved a remarkable growth in agriculture, increasing food grain production from $83 \mathrm{mt}$ in 1960-61 to about $252.23 \mathrm{mt}$ in 2015-16. To augment food grain production, fertilizer consumption raised abruptly from 1 million tonnes (1960) to 25.6 million tonnes in 2016-2017 (FAI, 2017).

First of all, chemical fertilization was already crucial in the first half of the 1950s for the replenishment of soil nutrients. Without it soil nutrient balance would have been negative for both $\mathrm{N}$ and $\mathrm{P}$ although it would have remained 
positive for K. According to FAI (Fertilizer Association of India), the NPK ratio in India altered viz., $4.6: 2: 1$ in 2008-09, 4.3:2:1 in 2009-10, 6.5:2.9:1 in 2011-12, 8.2:3.2:1 in 2012-13 and 7.8:3.2:1 in 2015-2016 against the ideal ratio 4:2:1. Excessive use of fertilizers and associated chemical pesticides escort erosion of soil fertility, buildup of toxicity, loss of nutrients and deprivation of beneficial microbes.

Rice is the most important food crop around the world; in spite of its high domestic consumption. At present rice is grown in 158 million hectares throughout the world. China and India account for 55 percent of world rice production (FAO, 2017). In Anaimalai block of Tamil Nadu, rice is grown under larger area of 1500 ha. Presently, fluctuation in productivity and yield reduction is a flattering problem amongst farmers. Continuous cropping for enhanced yield removes substantial amounts of nutrients from soil in addition to that imbalanced use of chemical fertilizers, improper irrigation and various cultural practices also affect the soil quality rapidly (Medhe et al., 2012). Inorganic fertilizer in improving fertility has been reported as futile owing to certain limitation such as decline in soil organic carbon, inappropriate use of chemical fertilizers, monocropping systems and reduction in beneficial microbial activity in soil (Shen et al., 2010).

Hence soil fertility fluctuates throughout crop growing season each year due to alteration in quantity and availability of nutrients added by fertilizers, manure and compost. Evidence for rapidly changing nutrients in different ecosystems has also been reported (Bellamy et al., 2005; Chen et al., 2010). It was estimated that about 4.17 million tonnes of nitrogen, 2.13 million tonnes of phosphorus and 7.42 million tonnes of potassium are removed annually by agricultural cropping in India
(Biswas and Mukerjee, 2001), thus affecting the soil nutrient availability (Zargar 2009). This has been aggravated by the negative nutrient balances of most cropping systems (Vlek et al., 1997). Similar is the case with micronutrients like $\mathrm{Zn}, \mathrm{Fe}, \mathrm{Cu}$ and $\mathrm{Mn}$ deficiency can cause nutritional imbalance in the soils which may results in significant reduction in productivity (Wani et al., 2014). Therefore, variation in soil properties should be continuously monitored and studied to understand the effects of different management systems on soils. The importance of reliable and timely information on soils cannot be overlooked in order to acquire spatial information of the soil properties, such information are necessary in the implementation of effective management strategies for sustainable agricultural production (Denton et al., 2017). So, based on these views the survey has been conducted to assess the availability of the soil nutrient status in rice growing areas in Anaimalai Block, Coimbatore district of Tamil Nadu.

\section{Materials and Methods}

\section{Description of the study area}

Anaimalai Block situated in Coimbatore district of Tamil Nadu with latitude $10^{\circ} 34^{\prime} 57.29^{\prime \prime} \mathrm{N}$ and longitude of $76^{\circ} 57^{\prime} 10.02^{\prime \prime}$. It is positioned at a junction of Eastern Ghats and Western Ghats and has a general northwest-southeast trend with tropical climate. The summer receives high and winter receives very minimum rainfall with average precipitation of $1348 \mathrm{~mm}$. The average annual temperature in Anaimalai is $27.0{ }^{\circ} \mathrm{C}$. Canal irrigation is the major source of irrigation.

\section{Cropping pattern}

In Anaimalai block, rice is cultivated under three different seasons viz., Kar (May-June), Samba (Aug) and Navarai (Dec-Jan). The 
major cropping pattern of Rice-Rice-Pulses and Rice-Rice-Green manures were being followed by the farmers and routinely they grow green manure as offseason crop and incorporate it into the soil at the time of flowering stage.

\section{Soil sampling and analysis}

The accuracy and utility of soil test results depends on soil sampling precision. To fulfill the objective, 72 surface soil samples $(15 \mathrm{~cm}$ depth) were collected at the rate of four samples per village, from 18 villages in Anaimalai block with latitude and longitude values by Global Positioning System (GPS).

\section{Fertilizer packages followed in sampled area}

Based on the collected information, the fertilizer practice for rice followed in eighteen villages revealed that nitrogen was excessively used (150-230 $\left.\mathrm{kg} \quad \mathrm{N} \mathrm{ha}^{-1}\right)$ than the recommended dose. With regard to phosphorus, more than 70 percent of the farms received sufficient phosphorus and it was supplied in the form of complex fertilizers and DAP and 15 per cent of the farms were applied with excess $\mathrm{P}$ (20-30 kg of $\mathrm{P}_{2} \mathrm{O}_{5} \mathrm{ha}^{-1}$ ) but regarding potassium the trend was reverse that most of the farms received 35 percent lesser than the recommended dose $\left(50 \mathrm{~kg} \mathrm{ha}^{-}\right.$ $\left.{ }^{1}\right)$. Requirement of micronutrients is met through the micronutrient mixtures.

\section{Physicochemical analysis of soil samples}

Totally seventy soil samples were collected randomly with soil auger from a depth of 0-15 $\mathrm{cm}$ in Anaimalai block which belongs to the Irugur and Palladam soil series. The soil physico-chemical parameters viz., $\mathrm{pH}$, electrical conductivity (EC), organic carbon, available nitrogen, phosphorus, potassium and DTPA Fe, Zn, Mn and $\mathrm{Cu}$ were analyzed by using standard analytical methods. Soil pH was measured in a 2:1 water/soil ratio with a shaking time of about 30 minutes (ELICO LI615 pH meter). Salinity was determined by measuring the electrical conductivity of the saturated soil extract given by Jackson (1967) EC (ELICO CM 180 Conductivity meter). Organic carbon was estimated by Chromic acid wet digestion method given by Walkley and Black (1934). Available $\mathrm{N}$ in soil was determined by alkaline permanganate method (Subbiah and Asija, 1956) and available P was analysed by $0.5 \quad \mathrm{M} \quad \mathrm{NaHCO}_{3} \quad(\mathrm{pH} \quad 8.5$ ) Colorimetric with ascorbic acid reduction method by (Olsen 1954). Exchangeable K was estimated by flame photometer following soil extraction with Neutral Normal $\mathrm{NH}_{4} \mathrm{OAc}$ (Standford and English, 1949). Sulphur $\left(\mathrm{CaCl}_{2}\right.$ method), Boron (Hot water soluble method) and Micronutrients (DTPA extract and Atomic Absorption Spectrometry method, Jackson (1973)) were analysed.

\section{Nutrient availability index (NAI)}

To appraise the fertility status of soils in the study area, different soil properties affecting nutrient availability including $\mathrm{pH}$, electrical conductivity, organic carbon, available $\mathrm{N}, \mathrm{P}$, $\mathrm{K}$, iron, manganese, zinc and copper were included. Here the nutrient index was worked out based on the formula given by Bajaj and Ramamurthy et al., (1969). The nutrient index with respect to organic carbon, available N, P, and $\mathrm{K}, \mathrm{S}, \mathrm{B}$, and micronutrients were used to evaluate the fertility status of soils in the 18 villages. Nutrient Index Value $=$ (per cent samples in low category $\mathrm{x} 1+$ percent samples in medium category $\mathrm{x} 2+$ per cent samples in high x 3) /100

\section{Sulphur Availability Index (SAI)}

Sulphur Availability Index is derived as a key to assess the available $\mathrm{S}$ status in soils (Basumatary and Das, 2012). 
$\mathrm{SAI}=\left(0.4 \times \mathrm{CaCl}_{2}\right.$ extractable $\mathrm{SO}_{4}{ }^{-}$in $\mathrm{mg} \mathrm{kg}^{-}$ ${ }^{1}$ soil) $+\%$ organic matter

Using statistical software package the statistical analysis and correlation studies were executed for soil samples and Pearson correlation matrix was used to locate the relationship between the two variables. Guildford's thumb rule was taken for the interpretation of the Pearson product moment correlation (Guildford, 1973)

\section{Results and Discussion}

\section{Soil fertility status of study area}

The data of physico-chemical parameters of soil samples are presented in Table 1.

\section{Soil reaction $($ Soil $\mathrm{pH})$}

Plant nutrients availability and accordingly soil fertility are affected by $\mathrm{pH}$. Nutrient solubility varies in response to $\mathrm{pH}$, which predominantly affect the accessibility of nutrients by plants (Clark and Baligar, 2000). Analysis of soil $\mathrm{pH}$ showed that soil reaction ranged from neutral to alkaline $(6.59-8.87)$ across the soil samples. The highest $\mathrm{pH}$ value of 8.87 was recorded in the Kaliyapuram village followed by Periapodhu (8.71) and Kariyanchettipalayam (8.60) and 60 percent of samples were falls under the alkaline category. According to Brady and Weil (2005), alkalinity problem in soils arised due to indigenous calcareous parent material with typical low organic matter content. Soils of Somandhurai, Pilchinampalayam and Thensithur villages were identified under neutral category of soil reaction. In soils of Pethanaickanur, Thensangampalayam, Jallipatti, Subbegoundanpudhur, Marappagoundanpudhur, Anaimalai and Athupollachi village $\mathrm{pH}$ falls under the range of 7.01 to 7.89 . For normal rice growth, $\mathrm{pH}$ range should be 5.5-8.0 which facilitates better growth development (Zhoa et al., 2014). Therefore, observed $\mathrm{pH}$ in sampled area is favourable for rice cultivation (Table 3).

Among the three major nutrients, $\mathrm{N}$ (urea) is being excessively used than $\mathrm{P}$ and $\mathrm{K}$. In spite of ammonium based fertilizer (urea), undeniably there might be a chance of fertilizer induced acidification (Mustafa et al., 2018). However urea fertilization seemed to generate more significant change in soil $\mathrm{pH}$ in acid paddy soil than in alkaline paddy soil (Hong et al., 2018). The study areas have near neutral to alkaline condition with mean $\mathrm{pH}$ values of 6.5 to 8.8. Consequently, a change in $\mathrm{pH}$ was observed as urea was applied surplus than the actual plant requirement. Also acid and base forming cations influences the soil $\mathrm{pH}$ to a great extent (Reuss, and Johnson, 2012). In this case, added urea possibly results in base forming cations $\left(\mathrm{NH}_{4}^{+}\right)$which upon hydrolysis increases alkalinity through the discharge of $\mathrm{OH}-$ ions into soil solution. As a result, the effects of excess urea application could cause the effects by changing soil $\mathrm{pH}$ in acid paddy soil than the alkaline soil along with that base forming cations also responsible factor for maintaining such alkalinity even towards the long time application of excess $\mathrm{N}$. From pearson correlation matrix, $\mathrm{pH}$ was identified as negatively correlated with $\mathrm{N}$ ($0.099)$ and $\mathrm{Zn}(-0.109)$.

\section{Electrical conductivity (EC)}

The electrical conductivity indicates degree of salinity, and its excessive soluble salts in soil solution creates pessimistic impacts on uptake process either by imbalance in ion uptake, antagonistic effect between the nutrients or excessive osmotic potentials of soil solution or a combination of the three effects (Visconti et al., 2010). EC measured in soil samples collected from the Anaimalai block falls within the safer limit. It ranged between 0.15$0.32 \mathrm{dS} \mathrm{m}^{-1}$. Among all the villages the 
highest EC was observed in Arthanaripalayam village $\left(0.32 \mathrm{dS} \mathrm{m}^{-1}\right)$ and remaining villages were under the nonsaline category. Soil electrical conductivity is a measurement that correlates with soil properties that affect productivity, including cation exchange capacity (CEC), drainage conditions, organic matter level, salinity, and subsoil characteristics (Corwin and Lesch, 2010).

Generally phosphorus fertilizers have the tendency to raise the EC level of soil (Naima et al., 2015). However, the present fertilizer practices followed in the study area did not show any effect on soil EC (Table 4).

\section{Soil organic carbon (OC)}

Soil is known as the largest terrestrial carbon pool on earth where soil organic matter (SOM) constitutes the important biologically active form (Bhattacharyya et al., 2013).

Role played by organic carbon is vital for agricultural soils which supplies plant nutrients, improves soil structure, improves water infiltration and retention, feeds soil micro flora and fauna, and augment retention and cycling of applied fertilizer (Johnston et al., 2009).

The organic carbon content of the soils in the study area varied from 0.24 to 0.54 per cent (Table 5). The highest mean organic carbon value was recorded in Periapodhu $(0.54 \%)$ and Pethanaickanur $(0.52 \%)$ and lowest content in Pilchinampalayam (0.24\%) and Kambalapatty $(0.27 \%)$. The study revealed that more than $70 \%$ of soil samples were found in the medium ( 0.5 to $0.75 \%)$ category and remaining villages were under the lowest category $(<0.50 \%)$. The maintenance of SOM is desirable for long-term land use because of the manifold beneficial effects of organic matter on nutrient status, water holding capacity and physical structure (Alekhya et al., 2015; Shukla et al., 2004). Thus majority of rice grown areas are medium in organic carbon. According to Kavitha and Sujatha (2015), high levels of organic matter not only provides part of the $\mathrm{N}$ requirement of crop plants, but also enhance nutrient and water retention capacity of soils and create favourable physical, chemical and biological environment. It minimizes negative environmental impacts, and thus improves soil quality (Farquharson et al., 2003).

Paddy soils has the tendency to accumulate SOM (Pan et al., 2004) and represent an important carbon pool due to their high capacity for carbon sequestration under inundated soil conditions. Investigation on SOM accumulation in paddy soils revealed that organic carbon (OC) contents in paddy soils was significantly raised compared to non-inundated agricultural soils (Kalbitz et al., 2013; Wissing et al., 2013), which was ascribed to the OC buildup by the paddy siltand clay-sized fractions (Wissing et al., 2011). Additionally, it has been suggested that these higher OC contents in paddy soils are attributable to a plant residue or stubbles (Lehndorff et al., 2014) in combination with the slower rates of OM decomposition that occur under inundated anaerobic soil conditions (Lal, 2002; Sahrawat, 2004; Zhang and $\mathrm{He}, 2004)$.

It has similarly been suggested that continuous wetland rice cultivation would enhance the accumulation of lignin residues in topsoils (Olk et al., 2002) because they are highly resistant to degradation under anaerobic conditions (Colberg, 1988). Thus rice is cultivated continuously for more than decades in the study area, which might have added considerable quantity of plant residues and stubbles after every harvest of crop and thus on decomposition of the same would have contributed and maintained medium status OC in the soil. 


\section{Available nitrogen $(\mathbf{N})$}

$\mathrm{N}$ was considerably the nutrient with larger flow in the agro ecosystem topsoil. The available nitrogen content ranged from 140 to $300 \mathrm{~kg} / \mathrm{ha}$. More than 90 percent of the soils were deficient $\left(<280 \mathrm{~kg} \mathrm{ha}^{-1}\right)$ in available nitrogen. According to the fertility ratings, 93 per cent of soil samples which belongs to the villages viz., Divansipudhur, Subbegoundanpudhur and Pilchinampalayam were under the low category $(<0.5 \%)$ and the remaining 7 percent was medium in status $(0.5$ - $0.75 \%$ ). Even though $\mathrm{N}$ was applied in excess, the build of $\mathrm{N}$ in soil was unseen. Medium status of $\mathrm{N}$ were noticed in Somandhurai, Angalakurichi and Pethanaickanur villages as 300, 254 and 235 $\mathrm{Kg} /$ ha respectively. Such variation in available $\mathrm{N}$ content may be attributed to soil management, application of FYM and fertilizer to previous crop.

Most of the farms had given excess $\mathrm{N}$ than recommended level, and its interaction may have antagonistic effect over the other nutrients. As this region receives high rainfall $(1348 \mathrm{~mm})$ every year, available $\mathrm{N}$ might have leached out and resulting in low available $\mathrm{N}$ in the study area. Denitrification can be major loss mechanism of $\mathrm{NO}_{3}{ }^{-} \mathrm{N}$ when the soil is under saturation. Buresh and Datta (1990) reported that denitrification has long been considered a major loss mechanism for $\mathrm{N}$ fertilizer applied to lowland rice (Oryza sativa L.) Also continuous and intensive cultivation leads to high crop removal together with insufficient replenishment might be the reason for the high degree of nitrogen deficiency in soils Amara et al., (2017).

The medium status OC content of the soil may be attributed to low level of $\mathrm{N}$ in the soil which is also evidenced on the positive correlation obtained between OC and available nitrogen $(0.132)$.

\section{Available phosphorus (P)}

Compared to $\mathrm{N}$, phosphorus had only negligible nutrient flow in cropping system. $\mathrm{P}$ is a unique ion essential for root development, energy storage and transfer of nutrients, get entered into soil solution all the way through mineral fertilizers or mineralization of organophosphates. Plants can take up $\mathrm{P}$ ion by and large in the form of $\mathrm{H}_{2} \mathrm{PO}_{4}^{-}$which was available at $\mathrm{pH}$ 7.2. The level of phosphorous in study area varied from 15 to $22 \mathrm{~kg} \mathrm{ha}^{-1}$.

Its mean content was significantly high in soils of Anaimalai, Subbegoundanpudhur and Athupollachi villages which covers 18 percent of the total collected samples and low in Thensamgampalayam and Angalakurichi villages $\left(15 \mathrm{~kg} \mathrm{ha}^{-1}\right)$. A high proportion of soil samples $(80 \%)$ were medium in available phosphorus (15-22 kg/ha), which may be due to the sufficient contribution of phosphate fertilizers over a period of time (Denis et al., 2017). Based on survey, $P$ was sufficiently provided, even though its interaction was negatively correlated with $\mathrm{Fe}, \mathrm{Cu}$ and $\mathrm{Mn}$ (Table 6). Positive correlation between $\mathrm{P}$ and OC was noted. Nye and Bertheux (1957) reported that mineralization of organic $\mathrm{P}$ is a concomitant reaction with the oxidation of organic matter which contribute $12 \mathrm{~kg}$ per ha of available $\mathrm{P}$ to the surface layers and also declining reserves of organic matter during subsequent cropping periods however, could not restore concentration of inorganic $\mathrm{P}$ at levels high enough to maintain adequate yields. Application of recommended dose of $\mathrm{P}$ coupled with $\mathrm{P}$ addition through the process of decomposition of organic manure may be attributed to high level of $\mathrm{P}$ in the rice soil.

\section{Available potassium (K)}

Large number of enzymes participated in physiological process gets activated by $\mathrm{K}$ ion only. From the study, accumulation of $\mathrm{K}$ in 
soil obtained by fertilizer $\mathrm{K}$ input is not enough to cope with the plant need. Almost all the farmers apply muriate of potash as source of $\mathrm{K}$. Input application of $\mathrm{K}$ was not in accordance with recommended level for rice. Most of the rice farms were applied with lesser quantity of $\mathrm{K}(33$ per cent lesser than RDF). Totally ninety per cent of the soil samples were medium in available $\mathrm{K}$. Its mean content was significantly high in soils of Divansipudhur (228 kg ha-1) and low in soils of Angalakurichi $\left(108 \mathrm{~kg} \mathrm{ha}^{-1}\right)$. The leaching condition brought in by rainfall does not permit retention of potassium on the soil exchangeable complex which might be the probable reason for the low potassium status $\left(<280 \mathrm{~kg} \mathrm{ha}^{-1}\right)$ of these soils (Pulakeshi et al., 2012). The low available $\mathrm{N}$ recorded in this present study may be attributed to have lesser exchange with potassium on the soil exchange complex and thus potassium was maintained in medium status (Nguyen, 2003). K is in positive correlation with other nutrients except manganese.

Table.1 List of villages with GPS coordinates

\begin{tabular}{|c|l|l|}
\hline S. No & \multicolumn{1}{|c|}{ Name of the villages } & \multicolumn{1}{|c|}{ GPS Readings } \\
\hline $\mathbf{1 .}$ & Pethanaickanur & $10.5766^{\circ} \mathrm{N}, 76.9744^{\circ} \mathrm{E}$ \\
\hline $\mathbf{2 .}$ & Ramanamudhalipudhur & $10.3339^{\circ} \mathrm{N}, 76.5828^{\circ} \mathrm{E}$ \\
\hline $\mathbf{3 .}$ & Thensamgampalayam & $10.5474^{\circ} \mathrm{N}, 76.9672^{\circ} \mathrm{E}$ \\
\hline $\mathbf{4 .}$ & Somandhurai & $10.5701^{\circ} \mathrm{N}, 76.9845^{\circ} \mathrm{E}$ \\
\hline $\mathbf{5 .}$ & Angalakurichi & $10.5334^{\circ} \mathrm{N}, 76.9945^{\circ} \mathrm{E}$ \\
\hline $\mathbf{6 .}$ & Kariyanchettipalayam & $10.3410^{\circ} \mathrm{N}, 77.0049^{\circ} \mathrm{E}$ \\
\hline $\mathbf{7 .}$ & Kambalapatty & $10.5523^{\circ} \mathrm{N}, 77.0370^{\circ} \mathrm{E}$ \\
\hline $\mathbf{8 .}$ & Arthanaripalayam & $10.5367^{\circ} \mathrm{N}, 77.0572^{\circ} \mathrm{E}$ \\
\hline $\mathbf{9 .}$ & Divansipudhur & $10.6294^{\circ} \mathrm{N}, 76.8714^{\circ} \mathrm{E}$ \\
\hline $\mathbf{1 0 .}$ & Jallipatti & $10.5367^{\circ} \mathrm{N}, 75.0572^{\circ} \mathrm{E}$ \\
\hline $\mathbf{1 1 .}$ & Pilchinampalayam & $10.3536^{\circ} \mathrm{N}, 77.0573^{\circ} \mathrm{E}$ \\
\hline $\mathbf{1 2 .}$ & Subbegoundanpudhur & $10.6286^{\circ} \mathrm{N}, 76.9326^{\circ} \mathrm{E}$ \\
\hline $\mathbf{1 3 .}$ & Periapodu & $10.6099^{\circ} \mathrm{N}, 76.8807^{\circ} \mathrm{E}$ \\
\hline $\mathbf{1 4 .}$ & Marappagoudanpudhur & $12.6863^{\circ} \mathrm{N}, 81.7209^{\circ} \mathrm{E}$ \\
\hline $\mathbf{1 5 .}$ & Anaimalai & $10.5826^{\circ} \mathrm{N}, 76.9528^{\circ} \mathrm{E}$ \\
\hline $\mathbf{1 6 .}$ & Kaliyapuram & $10.5400^{\circ} \mathrm{N}, 76.9211^{\circ} \mathrm{E}$ \\
\hline $\mathbf{1 7 .}$ & Thensithur & $10.5646^{\circ} \mathrm{N}, 76.9845^{\circ} \mathrm{E}$ \\
\hline $\mathbf{1 8 .}$ & Athupollachi & $10.6487^{\circ} \mathrm{N}, 76.9197^{\circ} \mathrm{E}$ \\
\hline & & \\
\hline
\end{tabular}


Table. 2 Ratings followed for calculating the nutrient index

\begin{tabular}{|l|c|c|c|c|}
\hline Soil Properties & Unit & \multicolumn{3}{|c|}{ Range } \\
\hline Soil pH & $\mathrm{pH}$ & $<6.5$ (Acidic) & $6.5-7.5$ (Neutral) & $>7.5$ (Alkaline) \\
\hline EC & $\mathrm{dS} \mathrm{m}^{-1}$ & Upto1(Non saline) & $1.1-3.0$ (Slightly saline) & $>3$ (Saline) \\
\hline $\begin{array}{l}\text { Organic } \\
\text { Carbon }\end{array}$ & $\%$ & $<0.5$ (Low) & $0.5-0.75$ (Medium) & $>0.75$ (High) \\
\hline KMnO $4-\mathbf{N}$ & $\mathrm{Kg} \mathrm{ha}^{-1}$ & $<280$ (Low) & $280-450$ (Medium) & $>450$ (High) \\
\hline OIsen $-\mathbf{P}$ & $\mathrm{Kg} \mathrm{ha}^{-1}$ & $<11$ (Low) & $11-22$ (Medium) & $>22$ (High) \\
\hline NH $4 \mathbf{O A A c}-\mathbf{K}$ & $\mathrm{Kg} \mathrm{ha}^{-1}$ & $<118$ (Low) & $118-280$ (Medium) & $>280$ (High) \\
\hline DTPA-Fe & $\mathrm{mg} \mathrm{kg}^{-1}$ & $<3.7$ (Deficient) & $3.7-8.0$ (Moderate) & $>8.0$ (Sufficient) \\
\hline DTPA-Mn & $\mathrm{mg} \mathrm{kg}^{-1}$ & $<2.0$ (Deficient) & $2.0-4.0$ (Moderate) & $>4.0$ (Sufficient) \\
\hline DTPA-Zn & $\mathrm{mg} \mathrm{kg}^{-1}$ & $<1.2$ (Deficient) & $1.2-1.8$ (Moderate) & $>1.8$ (Sufficient) \\
\hline DTPA-Cu & $\mathrm{mg} \mathrm{kg}^{-1}$ & $<1.2$ (Deficient) & $1.2-1.8$ (Moderate) & $>1.8$ (Sufficient) \\
\hline
\end{tabular}

Table.3 Based on SAI value, the soils were grouped into three categories

\begin{tabular}{|c|c|}
\hline Value & Interpretation (Sulphur availability) \\
\hline$<\mathbf{6 . 0}$ & Low \\
\hline $\mathbf{6 . 0}$ to 9.0 & Medium \\
\hline$>9.0$ & High \\
\hline
\end{tabular}


Table.4 Chemical properties of soil samples collected from eighteen villages in Anaimalai Block

\begin{tabular}{|c|c|c|c|c|c|c|c|c|c|c|c|c|c|c|}
\hline $\begin{array}{l}\ddot{Z} \\
\dot{n}\end{array}$ & Name of the villages & 졸 & ט & $0 \sqrt{2}$ & 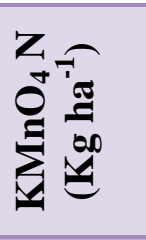 & 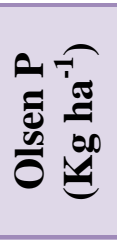 & 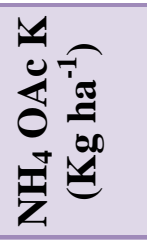 & 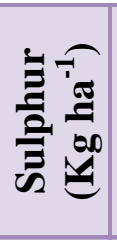 & 疋 & 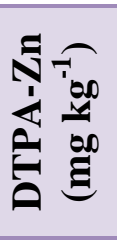 & 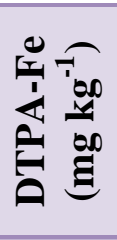 & 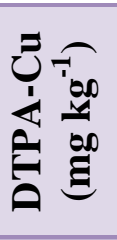 & 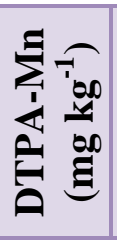 & 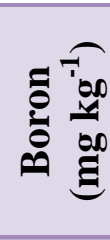 \\
\hline 1. & Pethanaickanur & 7.39 & 0.20 & 0.52 & 235.00 & 18.25 & 159.25 & 21.4 & 25.8 & 1.24 & 7.40 & 2.42 & 1.98 & 1.08 \\
\hline 2. & Ramanamudhalipudhur & 8.46 & 0.17 & 0.40 & 186.50 & 22.50 & 166.25 & 14.6 & 26.5 & 0.57 & 7.18 & 2.72 & 1.98 & 2.70 \\
\hline 3. & Thensamgampalayam & 7.01 & 0.19 & 0.45 & 228.25 & 15.25 & 152.00 & 20.4 & 24.3 & 1.23 & 4.48 & 3.48 & 2.29 & 2.53 \\
\hline 4. & Somandhurai & 6.59 & 0.16 & 0.52 & 300.25 & 17.75 & 156.50 & 19.9 & 22.3 & 1.57 & 7.46 & 2.88 & 2.41 & 1.96 \\
\hline 5. & Angalakurichi & 8.05 & 0.17 & 0.43 & 254.00 & 15.00 & 108.75 & 14.3 & 26.1 & 0.75 & 6.72 & 2.41 & 2.46 & 2.02 \\
\hline 6. & Kariyanchettipalayam & 8.60 & 0.16 & 0.31 & 257.25 & 21.00 & 170.50 & 21.3 & 23.1 & 1.13 & 7.26 & 3.14 & 2.45 & 2.15 \\
\hline 7. & Kambalapatty & 8.49 & 0.32 & 0.27 & 245.75 & 20.25 & 190.50 & 18.7 & 21.0 & 0.85 & 5.33 & 4.95 & 1.50 & 1.63 \\
\hline 8. & Arthanaripalayam & 8.28 & 0.15 & 0.40 & 209.50 & 19.00 & 200.50 & 23.1 & 26.2 & 1.29 & 6.80 & 4.25 & 2.34 & 1.03 \\
\hline 9. & Divansipudhur & 8.21 & 0.19 & 0.48 & 209.50 & 19.75 & 228.25 & 24.1 & 25.4 & 2.35 & 8.68 & 4.29 & 2.39 & 1.25 \\
\hline 10. & Jallipatti & 7.39 & 0.16 & 0.34 & 198.50 & 20.50 & 185.00 & 19.4 & 26.1 & 1.43 & 5.75 & 3.01 & 2.43 & 3.76 \\
\hline 11. & Pilchinampalayam & 6.72 & 0.27 & 0.24 & 174.00 & 19.50 & 169.75 & 20.3 & 26.0 & 0.60 & 4.82 & 1.95 & 1.64 & 2.35 \\
\hline 12. & Subbegoundanpudhur & 7.53 & 0.16 & 0.30 & 141.75 & 21.00 & 142.50 & 15.7 & 25.8 & 1.33 & 4.29 & 2.00 & 1.81 & 1.48 \\
\hline 13. & Periapodu & 8.71 & 0.23 & 0.54 & 181.75 & 16.75 & 179.50 & 18.3 & 25.6 & 1.13 & 5.97 & 2.01 & 2.31 & 1.11 \\
\hline 14. & Marappagoudanpudhur & 7.89 & 0.22 & 0.46 & 195.50 & 21.75 & 154.75 & 16.8 & 22.0 & 0.80 & 6.06 & 2.02 & 2.29 & 1.52 \\
\hline 15. & Anaimalai & 7.60 & 0.26 & 0.47 & 209.50 & 22.00 & 202.75 & 17.4 & 25.6 & 1.83 & 5.81 & 3.37 & 2.14 & 3.62 \\
\hline 16. & Kaliyapuram & 8.87 & 0.23 & 0.40 & 159.25 & 18.50 & 172.75 & 22.0 & 24.5 & 0.93 & 7.09 & 2.63 & 2.13 & 3.91 \\
\hline 17. & Thensithur & 6.96 & 0.24 & 0.53 & 154.25 & 19.50 & 174.00 & 21.5 & 24.2 & 0.94 & 6.47 & 2.90 & 1.96 & 2.40 \\
\hline 18. & Athupollachi & 7.79 & 0.18 & 0.43 & 187.25 & 22.00 & 201.25 & 23.1 & 24.3 & 1.33 & 5.38 & 1.57 & 1.87 & 1.83 \\
\hline
\end{tabular}


Table.5 Nutrient rating for macro and micro nutrients of surface soil samples from rice growing area of Anaimalai Block of Coimbatore

\begin{tabular}{|c|c|c|c|c|c|c|c|}
\hline \multirow{2}{*}{ Nutrients } & \multirow{2}{*}{ No of Sample } & \multicolumn{7}{|c|}{ Rating } \\
\cline { 3 - 8 } & & L & M & H & D & M & S \\
\hline Organic carbon & 72 & $50(69.5)$ & $22(30.5)$ & - & - & - & - \\
\hline KMnO $_{4}$ N & 72 & $67(93)$ & $5(7)$ & - & - & - & - \\
\hline Olsen P & 72 & $1(1.3)$ & $58(80.5)$ & $13(18)$ & - & - & - \\
\hline NH4 OAc K $^{\text {DTPA-Zn }}$ & 72 & $6(8)$ & $66(91.7)$ & - & - & - & - \\
\hline DTPA-Fe & 72 & - & - & - & $37(51.4)$ & $28(38.9)$ & $7(9.7)$ \\
\hline DTPA-Mn & 72 & - & - & - & $1(1.3)$ & $63(87.5)$ & $8(11.2)$ \\
\hline DTPA-Cu & 72 & - & - & - & $51(70.8)$ & $21(29.2)$ & - \\
\hline Sulphur & 72 & - & - & - & - & $17(23.6)$ & $55(76.3)$ \\
\hline Boron & 72 & - & - & - & - & - & $72(100)$ \\
\hline
\end{tabular}

(L: low; M: medium; H: high; D: deficient; M: moderate; S: sufficient)

(Numbers in the parenthesis denote percentage of samples falling within range)

Table.6 Nutrient index for macro and micronutrients in rice grown areas of Anaimalai block

\begin{tabular}{|l|l|c|c|}
\hline S. No & \multicolumn{1}{|c|}{ Nutrient } & Nutrient index & Fertility Rating \\
\hline $\mathbf{1 .}$ & Organic carbon & 1.305 & Low \\
\hline $\mathbf{2 .}$ & $\mathrm{KMnO}_{4} \mathrm{~N}$ & 1.07 & Low \\
\hline $\mathbf{3 .}$ & Olsen $\mathrm{P}$ & 2.163 & Adequate \\
\hline $\mathbf{4 .}$ & $\mathrm{NH}_{4} \mathrm{OAc} \mathrm{K}$ & 1.914 & Marginal \\
\hline $\mathbf{5 .}$ & Sulphur & 2.88 & Very high \\
\hline $\mathbf{6 .}$ & DTPA-Zn & 1.583 & Low \\
\hline $\mathbf{7 .}$ & DTPA-Fe & 2.099 & Adequate \\
\hline $\mathbf{8 .}$ & DTPA-Mn & 1.292 & Very low \\
\hline $\mathbf{9 .}$ & DTPA-Cu & 2.761 & Very high \\
\hline $\mathbf{1 0 .}$ & Boron & 3 & Very high \\
\hline
\end{tabular}

\section{Sulphur (S)}

In soils, $\mathrm{S}$ mostly remains in organic combination, constituting more than $95 \%$ (Wang et al., 2008) of total sulphur. Sulphur is required by crops in amounts comparable with $\mathrm{P}$ and one of the essential secondary macronutrient elements required for optimum growth, metabolism and development of all plants and is rightly called as the fourth major plant nutrient (Tripathi et al., 2018). On the whole S content ranges between 14.3 to 24.1 $\mathrm{mg} \mathrm{kg}^{-1}$. In Anaimalai block, availability of sulphur was found to be in surplus $(>15 \mathrm{mg}$ $\mathrm{kg}^{-1}$ ) in all the villages except Ramanamudhalipudhur (14.6 mg kg-1) and Angalakurichi (14.3 $\mathrm{mg} \mathrm{kg}^{-1}$ ). The highest S content (24.1 mg kg $\mathrm{mg}^{-1}$ was recorded in Divansipudhur followed by Arthanaripalayam (23.1 $\mathrm{mg} \mathrm{kg}^{-1}$ ).

The main source of sulphate in soils is through clay content and organic matter addition from plant and animal sources and inorganic fertilizes (Mess and Stoops, 2018). In the present study, organic carbon content 
of the soil was medium in status in 70 per cent of soil coupled with the addition of $\mathrm{SO}_{4}{ }^{-}$ through the phosphatic fertilizer may be contributed to the high $\mathrm{S}$ status of soils.

The sulphur availability index (SAI) values varied between 6 and 10. Based on the values of SAI, soils of Ramanamudhalipudhur (6.53), Thensangampalayam (6.46) and Angalakurichi (6.8) were low in S. Divansipudhur traced with high SAI of 10.47. Generally organic matter is a reservoir of S. As 90 per cent of $S$ is present in organic form, the OC of the rice soils are medium in status, which would have contributed enough $S$ and thus recorded high $\mathrm{S}$ status and higher SAI values. According to SAI concept, if a soil containing $\mathrm{SO}_{4}{ }^{-} \mathrm{S}$ content just above the critical limit and low in organic matter content $(<0.5 \%)$, it cannot be considered as sufficient in available sulphur, since there is less organic matter to support to inorganic fraction of $S$ in case of any depletion. In soil sulphur is continuously cycled between inorganic sulphur and organic forms of sulphur (Saha et al., 2018). It is also supported by positive correlation observed between SOC and S.

\section{DTPA exctracted micronutrients $(\mathrm{Zn}, \mathrm{Cu}$,} $\mathrm{Mn}$ and $\mathrm{Fe}$ )

With the intensive cropping of high yielding rice varieties, deficiencies of zinc initially and subsequently deficiencies of iron emerged as threats to sustaining high levels of rice productivity (Singh et al., 2018).

The status of micronutrients ( $\mathrm{Zn}, \mathrm{Cu}, \mathrm{Mn}$ and $\mathrm{Fe}$ ) was analyzed and given in Table 2 . The available zinc in soils varied from very low to high $(0.57-1.83 \mathrm{ppm})$. In the soils of Ramanamudhalipudhur $\left(0.57 \mathrm{mg} \quad \mathrm{kg}^{-1}\right)$, Angalakurichi $\left(0.75 \mathrm{mg} \mathrm{kg}^{-1}\right)$, Kambalapatty $\left(0.85 \mathrm{mg} \mathrm{kg}^{-1}\right)$, Pilchinampalayam $(0.60 \mathrm{mg}$ $\left.\mathrm{kg}^{-1}\right)$ and Marappagoudanpudhur $(0.80 \mathrm{mg} \mathrm{kg}$ $\left.{ }^{1}\right) \mathrm{Zn}$ deficiency was observed. Moreover 50 percent of the area surveyed in Anaimalai block was found to be deficient in available zinc. Remaining villages such as Pethanaickanur (1.24 mg $\left.\mathrm{kg}^{-1}\right)$, Thensamgampalayam (1.23 $\mathrm{mg} \mathrm{kg}-1)$, Kariyanchettipalayam $\quad\left(1.13 \mathrm{mg} \quad \mathrm{kg}^{-1}\right)$, Arthanaripalayam $\left(1.29 \mathrm{mg} \mathrm{kg}^{-1}\right)$, and Subbegoundanpudhur (1.33 mg kg-1) were found to have medium $\mathrm{Zn}$ content. 39 per cent of soil sample was moderate in $\mathrm{Zn}$. The $\mathrm{Zn}$ status in the soils of Anaimalai and Divansipudhur villages was sufficient $(>1.8$ $\left.\mathrm{mg} \mathrm{kg}{ }^{-1}\right)$. Deficiency of $\mathrm{Zn}$ might be due to the formation of $\mathrm{Zn}$-phosphates following large applications of $\mathrm{P}$ fertilizer (Kavitha and Sujatha, 2015) and also conversion of soluble $\mathrm{Zn}$ to other insoluble forms of $\mathrm{Zn}$ like zinc hydroxide/zinc carbonate in rice soil (Kavitha and Sujatha, 2015). Hence, their solubility and mobility may decrease resulting in reduced availability.

Iron is an important micro nutrient which involves in activation of more enzymes which plays a vital in physiological process of the plants. The availability ranges of $\mathrm{Fe}$ in anaimalai block were 4.29 to $8.68 \mathrm{mg} \mathrm{kg}^{-1}$. The samples collected from Thensamgampalayam (4.48 $\left.\mathrm{mg} \mathrm{kg}^{-1}\right)$ and Subbegoundanpudhur (4.29 $\mathrm{mg} \mathrm{kg}^{-1}$ ) villages were moderate in Fe content. Soil samples of Divansipudhur had sufficient Fe $(8.68 \mathrm{mg} \mathrm{kg}$ $\left.{ }^{1}\right)$. Nearly 87 per cent of soil was sufficient in $\mathrm{Fe}\left(8.3-9.4 \mathrm{mg} \mathrm{kg}^{-1}\right)$ status. Under anaerobic conditions ferric $\left(\mathrm{Fe}_{3}^{+}\right)$is reduced to ferrous $\left(\mathrm{Fe}^{2+}\right)$ which would have significantly increased its solubility in soils (Zhang et al., 2018).

As the study area maintained $>0.5$ percent of $\mathrm{OC}$ which would have contributed higher $\mathrm{Fe}^{2+}$ in the rice soils which was also reported by Hafeez et al., (2018). It's also evident from the study that positive correlation was obtained between Fe and OC. 
The DTPA extractable copper $(\mathrm{Cu})$ content in rice soil ranged from $1.50-4.95 \mathrm{mg} \mathrm{kg}^{-1}$. As per the fertility ratings (1.2-1.8 ppm), the $\mathrm{Cu}$ content was found to be sufficient in all villages of Anaimalai block (Table 1). The sample collected from Thensamgampalayam, Somandhurai,

Angalakurichi, Kariyanchettipalayam, Arthanaripalayam, Jallipatti, Anaimalai and Periapodu villages had high $\mathrm{Cu}$ content (> $2.0 \mathrm{mg} \mathrm{kg}^{-1}$ ). Out of total samples, 76 percent of samples were adequate in $\mathrm{Cu}$ content. The high $\mathrm{Cu}$ content recorded in 70 percent of the soil samples may be attributed to the production of organic complexing agents which might have solubilized and improved the availability (Cao and $\mathrm{Hu}, 2000$ ).

The Mn content of soil samples ranged from 1.5 to $2.4 \mathrm{mg} \mathrm{kg}^{-1}$. The highest $\mathrm{Mn}$ was recorded in Angalakurichi $\left(2.46 \mathrm{mg} \mathrm{kg}^{-1}\right)$ and very low in Kambalapatty village $(1.5 \mathrm{mg} \mathrm{kg}$ $\left.{ }^{1}\right)$. Seventy percent of the soil samples collected from the Anaimalai block was deficient in manganese. Manganese deficiency is, most often occurring in the soil with a pH above 6 and heavily weathered, tropical soils. It is typically worsened by cool and wet conditions (Alloway et al., 2008) and moreover very common in degraded paddy soil high in Fe content, accumulation of $\mathrm{H}_{2} \mathrm{~S}$. Since the study area was cultivated with rice for a long time and also the soil with high $\mathrm{Fe}$ content leads to such below level of $\mathrm{Mn}$ content in soil. Alkaline soils and the soils low in manganese rarely contain $>10 \mathrm{ppm}$ at any stage of submergence as it is precipitated as manganese content (Das et al., 1992).

\section{Boron}

Boron is water-soluble and is mobile in soilwater solutions. Boron is present in soil solution in several forms but, at soil $\mathrm{pH}$ of 5.5-7.5, the most dominant form is the soluble undissociated boric acid $\left(\mathrm{H}_{3} \mathrm{BO}_{3}\right)$. Plants take up boron from soil in the form of boric acid. It appears that much of the B uptake mainly follows water flow through roots. Critical level of deficiency of $\mathrm{B}$ in rice at tillering to panicle initiation is $5 \mathrm{mg} \mathrm{kg}^{-1}$ (Dobermann, 2000). The results showed that, the boron content ranged between 1.03 to $3.97 \mathrm{mg} \mathrm{kg}^{-1}$. Soil samples collected from Kaliyapuram (3.91 $\mathrm{mg} \mathrm{kg}^{-1}$ ) and Jallipatti (3.76 $\mathrm{mg} \mathrm{kg}^{-1}$ ) villages was rich in boron amongst other villages and in the remaining villages it was found between 2.0 and $1.0 \mathrm{mg} \mathrm{kg}^{-1}$. It is observed that boron content was found to be adequate in all the villages. Boron associated with humic colloids is the principal B pool for plant growth (Jones, 2012). The strongest evidence that $\mathrm{OM}$ affects the availability of soil B is derived from studies that show a positive correlation between levels of SOM and the amount of hotwater-soluble B (Rasheed, 2009). In the present study also B content was positively correlated with organic carbon content.

However, it has been observed that in most plant species the boron requirement for reproductive growth is much higher than for vegetative growth this is especially true for gramineaceous plants, which have the lowest boron requirement to maintain normal vegetative growth, but need as much boron as other species at the reproductive stage (Matoh et al., 1996). Hence the essentiality of boron for rice is vital and supplied in surplus amount as per the soil test values.

The study revealed that analysis of rice growing soils in Anaimalai block was neutral to alkaline and non-saline in nature. Organic carbon content ranged from low to medium across the locations. Majority of soils were medium in phosphorus and potassium and low in nitrogen. Despite $\mathrm{N}$ was applied above recommended level, available $\mathrm{N}$ was low in status (140- $\left.300 \mathrm{~kg} \mathrm{ha}^{-1}\right)$. With respect to micronutrients, except copper other three 
elements were deficient. From the nutrient index, $\mathrm{Cu}$ was above sufficiency range and $\mathrm{P}$, $\mathrm{Fe}$ was found adequate and the other elements were deficit in soil.

\section{Acknowledgement}

The author acknowledges the chairman and members for the valuable guidance and the National Institute of Plant Health Management for providing the fund to carry the research in successful manner.

\section{References}

Alekhya V V L, Pujar G S, Jha C S and Dadhwal V K. 2015. Simulation of vegetation dynamics in Himalaya using dynamic global vegetation model. Trop Ecol. 56: 219-231.

Alloway B J, Graham R D and Stacey S P. 2008. Micronutrient deficiencies in Australian field crops. In Micronutrient deficiencies in global crop production. Pp: 63-92. Springer, Dordrecht.

Amara D M K, Patil P L, Kamara A M and Saidu D H. 2017. Assessment of soil fertility status using nutrient index approach. Academia Journal of Agricultural Research. 5(2): 28-38.

Athanase, Cyamweshi Rusanganwa. 2013. Phosphate sorption characteristics of andosols of the volcanic highlands of Central African Great Lakes Region. Journal of Environmental Science and Engineering. A 2.2A: 89.

Bajaj, J. C and Ramamurthy, B. 1969. Available nitrogen, phosphorus and potassium status of Indian soils. Fertiliser News. 14: 25-28.

Bellamy P H, Loveland PJ, Bradley R I, Lark $\mathrm{R} \mathrm{M}$ and Kirk G.J.D. 2005. Carbon losses from all soils across England and Wales 1978-2003, Nature 437: 245248.

Bhattacharya S, Nikitas N, Garnsey J,
Alexander N A, Cox J, Lombardi D and Nash D F. 2013. Observed dynamic soil-structure interaction in scale testing of off shore wind turbine foundations. Soil Dynamics and Earthquake Engineering, 54: 47-60.

Boukhalfa-Deraoui N, Hanifi-Mekliche L and Mihoub A. 2015. Effect of incubation period of phosphorus fertilizer on some properties of sandy soil with low calcareous content, Southern Algeria. Asian Journal of Agricultural Research, 9: 123-131.

Brady N C and Weil R R. 1999. The nature and properties of soil 12 th ed.

Brady N C and Weil RR. 2005. The Nature and properties of soil (Thirteenth Edition) Macmillan Publishing Co. New York.

Buresh R J and De Datta S K. 1990. Denitrification losses from puddled rice soils in the tropics. Biology and Fertility of Soils, 9(1): 1-13.

Cao Z H and $\mathrm{Hu}$ Z Y. 2000. Copper contamination in paddy soils irrigated with wastewater. Chemosphere, 41(12): 3-6.

Chen F S, Fahey T J, Yu M Y and Gan L. 2010. Key nitrogen cycling processes in pine plantations along a short urbanrural gradient in Nanchang, China For Ecol Manag 259:477-486

Clark R B and Baligar V C. 2000. Acidic and alkaline soil constraints on plantmineral nutrition. Plant-Environment

Interactions, 2nd Ed.; Wilkinson, RE, Ed, 133177.

Colberg P J. 1988. Anaerobic microbial degradation of cellulose, lignin, oligolignols, and monoaromatic lignin derivatives. Biology of anaerobic microorganisms, 333-372.

Corwin D L and Lesch S M. 2010. Delineating site-specific management units with proximal sensors. In Geostatistical applications for 
precision agriculture. pp. 139-165.

Das S C, Mandal B and Mandal L N. 1991. Effect of growth and subsequent decomposition of blue-green algae on the transformation of iron and manganese in submerged soils. Plant and soil, 138(1): 75-84.

Denton O A. 2017. "Assessment of spatial variability and mapping of soil properties for sustainable agricultural production using geographic information system techniques (GIS)." Cogent Food \& Agriculture 3.1: 1279366.

Dobermann A. 2000. Rice: Nutrient disorders \& nutrient management (Vol. 1). Int. Rice Res. Inst..

Farquharson R J, Schwenke G D and Mullen J D. 2003. Should we manage soil organic carbon in Vertosols in the northern grains region of Australia? Australian Journal of Experimental Agriculture, 43(3): 261-270.

Guilford J P and Fruchter B. 1973. Fundamental statistics in psychology and education. New York: McGrawHill.

Hafeez B, Khanif Y M and Saleem M. 2013. Role of zinc in plant nutrition-a review. American journal of experimental Agriculture, 3(2): 374.

Hong S, Piao S, Chen A, Liu Y, Liu L, Peng $S$ and Zeng H. 2018. Afforestation neutralizes soil pH. Nature communications, 9(1): 520.

Jackson M L. 1973. Soil chemical analysis. Prentice Hall of India Private Limited, New Delhi.

Johnston A. E, Poulton P R and Coleman K. 2009. Soil organic matter: its importance in sustainable agriculture and carbon dioxide fluxes. Advances inagronomy, 101:1-57.

Jones Jr, J B. 2012. Plant nutrition and soil fertility manual. CRC press.

Kalbitz K, Kaiser K, Fiedler S, Kölbl A,
Amelung W, Bräuer T and Schwark L. 2013. The carbon count of 2000 years of rice cultivation. Global change biology, 19(4): 1107-1113.

Kavitha C and Sujatha M P. 2015. Evaluation of soil fertility status in various agro ecosystems of Thrissur District, Kerala, India. International Journal of Agriculture and Crop Sciences, 8(3): 328.

Lal R. 2002. Soil carbon sequestration in China through agricultural intensification, and restoration of degraded and desertified ecosystems. Land Degradation \& Development, 13(6): 469-478.

Lehndorff E, Roth P J, Cao Z H and Amelung W. 2014. Black carbon accrual during 2000 years of paddy- rice and non- paddy cropping in the Yangtze River Delta, China. Global change biology, 20(6): 1968-1978.

Medhe S R, Tankankhar V G and Salve A N. 2012. Correlation of chemical properties, secondary nutrients and micronutrient anions from the soils of Chakur Tahsil of Latur district, Maharashrta. Journal of Trends in life sciences: 1(2)

Mees F and Stoops G. 2018. Sulphidic and sulphuric materials. In Interpretation of micromorphological features of soils and regoliths. pp. 347-376. Elsevier.

Mustafa T S, Ali S S and Jacopo N. 2018. Environmental impact of rice production based on nitrogen fertilizer use. Environmental science and pollution research international.

Nguyen L T, Osanai Y, Lai K, Anderson I C, Bange M P, Tissue D T and Singh B K. 2018. Responses of the soil microbial community to nitrogen fertilizer regimes and historical exposure to extreme weather events: flooding or prolonged drought. Soil Biology and Biochemistry, 118: 227-236. 
Nye $\mathrm{P} H$ and Bertheux $M$ H. 1957. The distribution of phosphorus in forest and savannah soils of the Gold Coast and its agricultural significance. The Journal of Agricultural Science, 49(2): 141-159.

Olk D C, Cassman K G, Randall E W, Kinchesh P, Sanger L J and Anderson J M. 1996. Changes in chemical properties of organic matter with intensified rice cropping in tropical lowland soil. European Journal of Soil Science, 47(3): 293-303.

Pan G, Li L, Wu L and Zhang X. 2004. Storage and sequestration potential of topsoil organic carbon in China's paddy soils. Global Change Biology, 10(1): 79-92.

Pulakeshi H B P, Patil P L, Dasog G S, Radder B M, Bidari B I and Mansur C P. 2012. Mapping of nutrients status by geographic information system (GIS) in Mantagani village under northern transition zone of Karnataka. Karnataka Journal of Agricultural Sciences, 25(3).

Rahman and Zulfahmi A. 2010. Influence of oil contamination on geotechnical properties of basaltic residual soil. American journal of applied sciences. 7.7: 954.

Rasheed M K. 2009. Role of boron in plant growth: a review. J. Agric. Res, 47(3).

Reuss J O and Johnson, D W. 2012. Acid deposition and the acidification of soils and waters (Vol. 59). Springer Science $\&$ Business Media.

Saha B, Saha S, Roy P D, Padhan D, Pati S and Hazra G C. 2018. Microbial Transformation of Sulphur: An Approach to Combat the Sulphur Deficiencies in Agricultural Soils. In Role of Rhizospheric Microbes in Soil (pp. 77-97). Springer, Singapore.

Sahrawat K L. 2004. Organic matter accumulation in submerged soils. Advances in Agronomy, 81: 170203.
Shen J P, Zhang L M, Guo J F, Ray J L and He J Z. 2010. Impact of long-term fertilization practices on the abundance and composition of soil bacterial communities in Northeast China. Applied Soil Ecology. 46: 119-124.

Shukla M K, Slater B K, Lal R and Cepuder P. 2004. Spatial variability of soil properties and potential management classification of a chernozemic field in lower Austria. Soil Science, 169(12): $852-860$.

Singh C, Tiwari S, Gupta V K and Singh J S. 2018. The effect of rice husk biochar on soil nutrient status, microbial biomass and paddy productivity of nutrient poor agriculture soils. Catena, 171: 485-493.

Stanford G, English L, Comstock R E, Robinson H F and Harvey P H. 1949. Use of the flame photometer in rapid soil tests for $\mathrm{K}$ and $\mathrm{Ca}$. Agronomy journal, 41(9): 446-447.

Subbiah B V and G L. Asija. 1956. A rapid procedure for the determination of available nitrogen in soils. Current Science 25: 259-260.

Tarak Das Biswas S K. Mukherjee 2001. Textbook of Soil Sciences

Tian, Guangli. 2017. "Improving rice population productivity by reducing nitrogen rate and increasing plant density." PloS one 12.8: e0182310.

Tripathi L K, Ghosh S K, Patra P K and Gupta A K. 2018. Efficacy of organic and inorganic amendments on Sulphur availability in relation to growth and yield of rice in an Alfisol soil. IJCS, 6(2): 2992-2997.

Visconti F, de Paz J M and Rubio J L. 2010. What information does the electrical conductivity of soil water extracts of 1 to 5 ratio $(\mathrm{w} / \mathrm{v})$ provide for soil salinity assessment of agricultural irrigated lands? Geoderma, 154(3-4): 387-397.

Vlek P L G. and Craswell E T. 1979. Effect of nitrogen source and management on 
ammonia volatilization losses from flooded rice-soil systems. Soil Sci. Soc. Am. J. 43: 352- 358.

Walkley A and Black C A. 1934. An examination of method for determination of soil organic matter and a proposed modification of the chromic acid titration method. Soil Science. 37: 29-38.

Wang Y, Li Q, Hui W, Shi J, Lin Q, Chen X and Chen Y. 2008. Effect of sulphur on soil $\mathrm{Cu} / \mathrm{Zn}$ availability and microbial community composition. Journal of hazardous materials. 159(2-3): 385389.

Wani P A, Khan M S and Zaidi A. 2007. Effect of metal tolerant plant growth promoting Bradyrhizobium sp. (vigna) on growth, symbiosis, seed yield and metal uptake by greengram plants. Chemosphere, 70(1): 36-45.

Wissing L, Kölbl A, Häusler W, Schad P, Cao Z H and Kögel-Knabner I. 2013. Management-induced organic carbon accumulation in paddy soils: the role of organo-mineral associations. Soil and Tillage Research, 126: 60-71.

Wissing L, Kölbl A, Vogelsang V, Fu J R, Cao Z H and Kögel-Knabner I. 2011. Organic carbon accumulation in a 2000 - year chronosequence of paddy soil evolution. Catena, 87(3): 376-385.

Xu R K. 2002. Soil acidification as influenced by crop rotations, stubble management, and application of nitrogenous fertiliser, Tarlee, South Australia. Soil Research. 40.3: 483-496.

Zargar R. 2009. Relationship between some macronutrients of paddy growing soils of Kashmir and their contents in rice plants. Environment and Ecology. 27 (2): $885-887$

Zhang L, Tang Z, Zhang S, Jia X, Yu X, Sun $G$ and Zou Y. 2018. Effects of artificial aeration and iron inputs on the transformation of carbon and phosphorus in a typical wetland soil. Journal of Soils and Sediments, 112.

Zhang M and He Z. 2004. Long-term changes in organic carbon and nutrients of an Ultisol under rice cropping in southeast China. Geoderma, 118(3-4): 167-179.

Zhao J, Ni T, Li Y, Xiong W, Ran W, Shen B and Zhang R. 2014. Responses of bacterial communities in arable soils in a rice-wheat cropping system to different fertilizer regimes and sampling times. PloS one, 9(1): e85301.

\section{How to cite this article:}

Theresa, K., R. Shanmugasundaram and Kennedy, J.S. 2019. Assessment of Spatial Variability of Soil Nutrient Status in Rice Ecosystem Using Nutrient Index in Anaimalai Block, Coimbatore. Int.J.Curr.Microbiol.App.Sci. 8(08): 2169-2184. doi: https://doi.org/10.20546/ijcmas.2019.808.253 